УДК 75.03(091)(477)

DOI:

Оксана Самбірська, магістрант спеціальності “Образотворче мистецтво, декоративне мистецтво, реставрація" Дрогобицького державного педагогічного університету імені Івана Франка

\title{
ПОБУТОВИЙ ЖАНР УКРАЇНСЬКОГО ЖИВОПИСУ КРІЗЬ ПРИЗМУ НАЦІОТВОРЧИХ ПРОЦЕСІВ
}

У статті розглянуто історію становлення та розвитку побутового жанру украӥнського живопису. Охарактеризовано історико-культурні основи та естетичні аспекти побутового живопису. Культурномистеиька спадщина українського народу висвітлена крізь призму начіотворчих процесів. Розкрито потенційні можливості українського побутового живопису як складової національної культури в контексті начіонально-патріотичного впливу на особистість в умовах глобалізації сучасного сочіокультурного nростору.

Ключові слова: глобалізація; образотворче мистецтво; живопис; побутовий жанр; особистість; націотворення.

Jim. 5.

Oksana Sambirska, Master Student of the specialty “Fine Arts, Decorative Arts, Restoration" Drohobych Ivan Franko State Pedagogical University

\section{HOUSEHOLD GENRE OF UKRAINIAN PAINTING THROUGH THE PRISM OFTHE NATION-BUILDING PROCESSES}

The article considers the history of formation and development of genre of Ukrainian painting. It is established that in the Ukrainian art, the certain elements of a genre were presented in a miniature of hand-written books, in graphics, in iconography, in sculpture, in a portrait. However, they had only a secondary role. Only in the XVIIIearly XIX centuries, painting genre has established itself as a separate genre of Ukrainian art. The image of everyday life stood up as an expression of social and philosophical ideas of its time. The main features of the Ukrainian painting genre were humanistic sense, realistic visual forms and Ukrainian national identity.

The main themes of the Ukrainian painting genre were labor, drama and tragedy of real life of the people. Ukrainian artists, rethinking the traditions of European painting, developed their own style, which became the basis on which the second half of the XIX century - the beginning of the XX century the Ukrainian genre of painting has acquired an unprecedented flourishing. Ukrainian painting became the property of the general public and contributed to the formation of aesthetic tastes and the national-patriotic feelings of Ukrainians.

This analysis of the history of formation and development of genre of painting suggests that its works played a significant role in the national processes of Ukrainian society. The introduction of Ukrainian themes in paintings contributed to the preservation of ethnic culture and identity of Ukrainians, the formation of national culture of our people. This problem is particularly relevant today, when Ukrainian society in the context of globalization is in search of its own way of development, preservation of national identity and cultural distinctiveness.

We believe that the genre of painting as a component of Ukrainian national culture is an important factor of the national-patriotic impact on the individual in the context of globalization of modern socio-cultural space.

Keywords: globalization; an art; a painting; a genre of painting; the personality; the nation-building process.

П остановка проблеми. На сучасному етапі розвитку людства однією 3 найважливіших проблем стала глобалізація, що охопила усе світове суспільство. Особливо гостро глобалізаційні процеси відчуваються в соціокультурному просторі, адже новітні культурні форми (шоу-бізнес, мас-медіа, реклама тощо) гальмують розвиток національних культур, що призводить до масовості, стандартизації, уніфікації.

В умовах посилення глобалізаційних процесів перед сучасним українським суспільством постала проблема збереження національного соціокультурного простору. Сучасні дослідники констатують необхідність проведення відповідної державної культурної політики, яка забезпечить необхідні умови для розвитку й діяльності українського суспільства. Серед завдань, які негайно необхідно вирішити, особливо важливими $\epsilon$ збереження самобутності, унікальності культури, етнічної ідентичності українського народу. Особливої уваги й підтримки потребують явища культури, які творчо репрезентують українські народні традиції, духовні орієнтири, естетичні ідеали.

Українська національна ідея невіддільна від українського образотворчого мистецтва. Твори українського образотворчого мистецтва 
відіграють важливу роль “унацієтворчих процесах, у поступовому русі українства до модерної української нації, бо формували одну 3 найважливіших властивостей нації- -іi духовність, яка найперше проявляється через національні цінності, національний образ світу, національний характер, національну свідомість і самосвідомість" $[2,18]$.

Аналіз останніх досліджень та публікацій. Сучасні українські дослідники (Н. Авер'янова, М. Бака, М. Бровко, З. Гіптерс, Н. Долгая, Д. Кучерюк, Л. Левчук, В. Панченко, Л. Масол, Г. Меднікова, Л. Мізіна, Н. Миропольська, Б. Неменський, О. Олексюк, І. Росковшенко, О. Рудницька, Р. Шульга та інші) відзначають мистецтво як потужний соціокультурний засіб впливу як на суспільство, так на окрему особистість. Н. Авер'янова слушно зауважує, що образотворче мистецтво транслює в сьогодення найважливіші культурні, художні та національні цінності та дає “змогу поєднувати національне та мистецьке, давати синтез сутнісних параметрів українського буття в усьому обсязі, розвивати смислові зв'язки особистості 3 національною спільнотою" $[2,19]$.

Змістовною сторінкою образотворчого мистецтва, що виразно ілюструє соціальні процеси у житті українців є побутовий жанр. Попри очевидну унікальність значної кількості творів, побутовий жанр українського живопису як засіб національно-патріотичного впливу на особистість залишається мало дослідженим.

Мета статті - розкрити специфіку формування та розвитку побутового живопису в Україні, з'ясувати його роль і місце в українських націотворчих процесах.

Дослідники (В. Московченко, В. Афанасьєв, Ю. Белічко, Г. Юхимець, Д. Крвавич, В. Овсійчук, С. Черепанова, Т. Кари-Васильєва, О. Петрова, Г. Скляренко, О. Роготченко, Д. Горбачев, Л. Белічко, О. Авраменко, С. Кілесо, Д. Степовик, О. Гаврош) наголошують на невід'ємному зв'язку побутового живопису із народною традицією. Проте, не зважаючи на інтерес дослідників, ця проблема поки що не отримала належного висвітлення у сфері національно-патріотичного виховання.

Виклад основного матеріалу. В українському мистецтві певні елементи побутового жанру здавна були присутні в мініатюрі рукописних книг, в графіці, в іконописі, у скульптурі, в портреті. Однак їм відводилася лише другорядна роль. Лише у XVIII - поч. XIX століттях побутовий жанр утвердився як окремий жанр українського мистецтва.

Зображення повсякденності постало як вираження суспільних і філософських ідей того часу. На теренах України мистецтво кінця XVIII - початку XIX ст. грунтувалося як на старих релігійних засадах та й на нових світських естетичних настановах, які були пов'язані 3 “реальним, позбавленим схоластичних догм, сприйняттям людини і довкілля” [4, 252].

Митці прагнули передати багатобарвне життя українських селян в побутових умовах. Д. Степовик вважає, що розвиткові побутового жанру в образотворчому мистецтві сприяло посилення світських моментів в українській літературі $[5,145]$.

Головними ознаками українського живопису стали гуманістичний зміст і реалістичність образотворчих форм. Ренесансне світобачення, проблема "Людина і Всесвіт" поглибили духовні надбання українського побутового живопису, підкреслили українську національну самобутність.

Побутовий жанр живопису став засобом втілення соціально-культурних ідей соціуму, його морально-етичних ідеалів та суспільно-політичних поглядів. “Зазначена традиція була пройнята стверджувальним соціальним пафосом i символізувала національні устремління українства, цим самим сприяючи вихованню патріотизму, гордості та впевненості в своїх силах української людини" [2, 20].

Основними темами українського побутового жанру були праця, драми та трагедії реального життя, що “огорталися серпанком ідеалістичних настроїв, позитивних емоцій” [5, 146]. В. Боровиковський, Д. Левицький, В. Тропінін, К. Павлов, А. Мокрицький, В. Штеренберг, I. Сошенко та інші українські художники в своїх творах відтворили реальні сцен 3 життя пересічних українців. Побутові сюжети митців були наповнені не лише "оповідними нюансами, але й яскраво вираженою характерністю і глибоким, інколи навіть здраматизованим психологізмом" [1]. Українські митці, переосмислюючи традиції європейського живопису, виробили власний стиль, що став основою, на якій у другій половині XIX ст. початку XX ст. український побутовий живопис набув небувалого розквіт.

В цей період сформувалися національні школи в українському образотворчому мистецтві, що сприяло виявленню самобутньої української національної культури. Митці у своїх творах розкривали зміст народної філософії, культури, побуту. Н. Авер' янова зазначає, що поняття “дух нації” та "національна ідея" стали одними “з найважливіших у філософсько-світоглядних системах, без якого не можна зрозуміти й осягнути ідейну сутність української 
образотворчої спадщини”, в них “концентрувалися відповіді на найскладніші питання: задля чого живе нація, як вона реалізує себе в оточенні інших спільнот" $[2,20]$.

В зазначений період величезний вплив на весь подальший розвиток побутового жанру українського живописумала творчість Т.Г.Шевченка. Його твори дали могутній поштовх до пробудження української національної свідомості. Національні ідеї Т.Г. Шевченка, його світоглядні позиції визначили творчий шлях багатьох українських митців, які в своїх творах, присвячені українському народові, стверджували загальнолюдську цінність української культури. Українська тематика стала провідною у творчості митців, а побутовий жанр живопису досяг незнаного розквіту.

У Києві, Харкові, Одесі влаштовуються пересувні виставки, які завдяки творчості художників-передвижників (К. Трутовський, М. Кузнецов, С. Світославський, М. Пиморенко, К. Костанді, П. Нілус, О. Мурашко, І. Труш, С. Кишинівський, С. Васильківський та ін.) розкрили українське мистецтво як повноцінне й неповторне явище, що характеризувалося чітко окресленими національними ознаками і водночас залишилося невід'ємною складовою загальноєвропейського культурного простору. Український живопис став здобутком широких верств населення та сприяв формуванню естетичні смаки і національно-патріотичних почуттів українців.

Митці охоче зверталися до побутового жанру в живописі, який позначився виразними рисами національної своєрідності. В їхніх творах оспівувалась Україна, іiі природа, народ, з його життєвими турботами, своєрідним побутом. Я. Бобош зазначає, що важливою рисою “багатьох творів українського побутового живопису є виразне ліричне забарвлення, яке не рідко поєднується з м'яким, доброзичливим, суто українським національним гумором" [3, 222]. Українськіхудожники(К. Устиянович,Т.Копистинський, Т. Романчук, О. Скругок, С. Томасевич, Ю. Панькевич, I. Труш та інші) зуміли втілити в своїх творах важливі морально-естетичні проблеми нашого народу та утвердити український побутовий живопис як явище національної культури.

Побутовий жанр в українському живопису другої половини XIX i поч. XX ст. став багатозначним явищем. Твори українських художників проникнуті любов'ю до народу, відрізнялися тонким колоритом, шаною до українського побуту, традицій і звичаїв. Піднесення національної самосвідомості українства "актуалізувало патріотичну роботу митців по збиранню і консолідації культурних сил нації; активізувало діяльність, спрямовану на збереження історичної пам'яті українців, втілену в фольклорі, етнографії, творах мистецтва" [2, 20]. 3 цією метою були створені художні музеї, виставки, мистецькі об'єднання, друковані видання.

Побутовий жанр протягом XX століття займає вагоме місце в історії українського живопису, хоча в цей час українське образотворче мистецтво розвивалось в контексті західноєвропейських новацій (імпресіонізму, постімпресіонізму, модерну, постмодернізму). Цей період відзначився складними, часто суперечливими обставинами, коли соціальні, політичні, військові катаклізми значно вплинули на людську особистість, змінили ціннісні орієнтири суспільства. Незважаючи на це, “мета художників усієї країни була спільною удосконалення професійного рівня українського образотворчого мистецтва, вирішення проблеми співвідношення традиції та новаторства, підвищена увага до національної тематики творів з метою активізації національної самоідентифікації українства, духовне єднання митців, розділених кордонами України, їхнє прагнення творити самобутне національне обличчя українського мистецтва" $[2,20]$. В цей період вагомий внесок у розвиток побутового жанру внесли художники Т.Н. Яблонська, О.О. Шовкуненко, С.О. Григор'єв, О.О. Дейнека, М.Ф. Гуменюк, О.Х. Новаківський, Ю.І. Піменов, О.П. Курилас, П.П. Кончаловський, О.Л. Кульчицька, Г.С. Меліхов, М.С. Самокиш, Й.Й. Бокшай та інші, в творах яких повсякденне життя українського народу постало в своїй красі та різноманітності.

Висновки. Сьогодні українське суспільство в умовах глобалізації перебуває у пошуку власного шляху розвитку, збереження національної ідентичності та культурної самобутності.

У національно-культурному житті українського народу важлива роль належить побутовому живопису, який впродовж усього періоду свого розвитку не лише відображав зміст культурномистецьких потреб українського суспільства, але й був важливою передумовою художнього і суспільного розвитку українського народу, основою для формування самобутньої національної свідомої українців.

Проведений аналіз історії становлення та розвиткупобугового жанру українського живопису дозволяє стверджувати, що твори побутового живопису відігравали суттєву роль у націотворчих процесах українського народу. Запровадження української тематики в живописних творах 
сприяло збереженню етнічної культури та ідентичності українців, становленню національної культури нашого народу.

\section{ЛІТЕРАТУРА}

1. Августюк О. Відображально-виражальна природа та естетична направленість образотворчого мистецтва Волині XVIII - XX століть [Електронний ресурс] / О.Августюк. Режим доступу: URL https://eprints.oa.edu.ua/1350/ 1/Avgustjyk 210512.pdf

2. Авер'янова Н. Українське образотворче мистецтво як невід’ $є$ мний чинник етнозбереження та націєтворення / Н. Авер'янова// Українознавство. - 2009. - №13. - С.18 - 21.

3.Бобош Я.М.Провіднітенденціїзахідноукраїнського малярства останньої третини XIX століття / Я.М. Бобош // Вісник Національного університету “Львівська політехніка". Серія: Архітектура: збірник наукових праць. - 2015. №836. - C. 221-227.

4. Гриценко Т. Б. Культурологія / Т. Б. Гриценко, С. П. Гриценко, А. Ю. Кондратюк та ін. - К .: Центр учбової літератури, 2009. - 392 с.

5. Степовик Д. В. Українське мистецтво першої половини ХІХ століття / Д. В. Степовик. К.: Мистецтво, 1982. - 191 с.

\section{REFERENCES}

1. Avhustiuk, O. (2012). Vidobrazhalno-vyrazhalna pryroda ta estetychna napravlenist obrazotvorchoho mystetstva Volyni XVIII - XX stolit [Reflectiveexpressive nature and aesthetic orientation of the fine art of Volyn XVII - XX centuries]. Available at: https:/ leprints.oa.edu.ua/1350/1/Avgustjyk_210512.pdf [in Ukrainian].

2. Averianova, N. (2009). Ukrainske obrazotvorche mystetstvo yak nevidiemnyi chynnyk etnozberezhennia ta natsiietvorennia [Ukrainian arts as an integral factor in ethno-preservation and nation-building]. Ukrainian Studies. No.13, pp.18-21. [in Ukrainian].

3. Bobosh, Ya. M. (2015). Providni tendentsii zakhidnoukrainskoho maliarstva ostannoi tretyny XIX stolittia [Leading trends of Western Ukrainian painting of the last third of the XIX century]. Journal of the National University "Lviv Polytechnic". Series: Architecture: a collection of scientific works. No. 836, pp. 221-227. [in Ukrainian].

4. Hrytsenko, T. B., Hrytsenko, S. P.\& Kondratiuk, A. Yu. (2009). Kulturolohiia [Culturology]. Kyiv: Sentr uchbovoi literatury, 392 p. [in Ukrainian].

5. Stepovyk, D. V. (1982). Ukrainske mystetstvo pershoi polovyny XIX stolittia [Ukrainian art of the first half of the XIX century]. Kyiv: Mystetstvo, $191 \mathrm{p}$. [in Ukrainian].

Стаття надійшла до редакції 30.07.2018



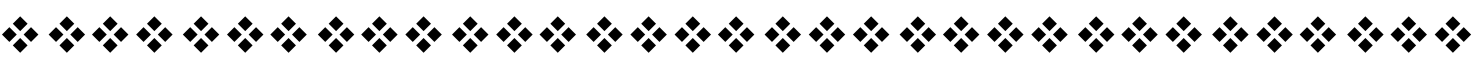 Dжерела мудрості} S

“Фовго сам учись, яқщо хочеш навчати інших".

Тригорій Сқоворода український поет, бөілособб

“Яюби істину, але будь поблажливим до помилок”.

Bольтер

nоет, прозаїк

“Чесність розуму поляаає в тому, щоб не відступати перед правдою. Мати сміливість иукати, судити і вирішувати самому. Мати сміливість самостійно мислити".

Ромен Роллан Французький письменник

\section{$\% * \% * \%$



